\title{
 \\ 子宮内膜異型増殖症における子宮鏡的不整血管の診断的重要性 Dose hysteroscopic observation of vascular irregularity improves upon the diagnostic sensitivity to atypical endometrial hyperplasia ?
}

\author{
東京医科大学産科婦人科学教室
}

\author{
清水禄子、小杉好紀、堀 量博、永田順子、井坂恵一、高山雅臣
}

\begin{abstract}
要旨
子宮内膜癌の早期診断における子宮鏡検査の有 用性について検討する目的で、既知の報告を総合 して考案した診断基準を用いて、過去 6 年間に外 来で子宮鏡検査を施行した 2177 例をレトロスペク ティブに解析した。その結果、子宮内膜癌 0 期と される子宮内膜異型増殖症（atypical endometrial hyperplasia :AEH）を、不整血管に着目した 場合には20.8\%のpositive predictive value (PPV) で正しく診断できるのに対して、内膜肥厚に着目 した場合には6.3\%であった。 negative predictive value（NPV）はいずれも100\%であった。

不整血管を観察することで、2次スクリーニング 検査としての子宮鏡検査の正診率が改善されるこ とが明らかになった。子宮内膜癌の早期発見に重 要とされる病理学的構造異型を簡便にスクリーニ ングする補助診断法として、子宮鏡検査で不整血 管を観察することの重要性が確認された。
\end{abstract}

\section{目的}

子宮内膜癌は近年増加傾向にあり、全子宮癌に 占める割合は約30\%にまで上昇している。1987年 より老人保健法に子宮体癌検診が導入され、子宮 内膜細胞診が広く行われているが、子宮頝癌の細 胞診に比べ手技的に困難で痛みを伴うにも関わら ず、その正診率は約60～70\%に留まるため、盲目 的に検体を採取する子宮内膜細胞診を補助する 数々の診断法が報告されている。例えば内膜の肥 厚の程度を定量化できる経腔超音波断層法や子宮 内に液体を注入して内膜表面の形状を明瞭化させ るソノヒステログラフィーなどが挙げられる。こ れらの検査法は、閉経後の症例に対してはその診 断能力と侵襲性の低さから有用性が認められるも
のの、月経周期によって変化する子宮内膜の性状 を質的に評価するには直視が可能な子宮鏡検査が 適しているといえる。特に子宮内膜癌の早期発見 を目的とした二次スクリーニング検査を考える場 合、内膜肥厚の程度といった量的評価に加え、内 膜がどのような状態にあるかという質的評価が必 要である。

子宮内膜癌の早期発見には、0 期とされる子宮 内膜異型増殖症 (atypical endometrial hyperplasia :AEH）を正確に診断することが肝要と考えら れるが、子宮鏡所見として、内膜の肥厚や腺口の 異常、そして血管の異常を認めるという報告があ るものの、いまだ確立された診断基準は存在しな $w^{1.23 .4)}$ 。一方近年、子宮内膜癌における子宮鏡検 查の病変検出感度は不十分であり子宮内膜掻爬術 を補完するものではない、との報告が散見される ようになった ${ }^{5,6,7,8,9)}$ 。そこで今回 我々は、子宮内 膜異型増殖症 (AEH) の子宮鏡所見に関する既 知の報告をもとに4 項目の評価基準を作成し、二 次スクリーニング検査としての子宮鏡検査の有用 性について検討した。

\section{対象と方法}

1994年 12 月〜 1999年 12 月迄の6年間に外来で 2177 例に子宮鏡検査を施行し、そのうち異常内膜 像を認めて狙い組織生検または子宮内膜掻爬術を 施行して病理組織診断を行った 242 例について retrospectiveに検討した。

子宮鏡検査には、主にオリンパス社製 HYFType X P または Type Tを使用した。

原則的に観察時期は増殖期に行い、生理的食塩 水を約 $80 \mathrm{~cm}$ 以下の落差圧で潅流し、必要に応じ て潅流液が腹腔内に播種していないことを経腹超 音波断層法を用いて確認した。 
評価基準として、1.内膜の肥厚形態・2. 血管の 不整・3.腺口の不均一・4色調の変化の 4 項目を 設けて検討した（図 1)。すなわち、1.内膜の肥 厚形態は全体的肥厚型・限局的肥厚型・単発ポリ ープ型・ポリポイド型・多発ポリープ型の5覀型 に分類した。2.血管の不整は、表在性の不規則な 走行と拡張であり、比較的平滑な表面に血管徍の 部分狭窄、怒張、蛇行した血管を認めるものとし た（写真 1 ）。3.腺口の不均一は、表面は比較的 平滑なものに大小不同の腺開口とばらつきのある 分布を認めるものとした (写真 2 )。4.色調の変 化は、比較的平滑な表面で黄白色〜灰白色を呈し 不透明なものとした（写真 3 )。

図 1 子宮内膜增殖症の子宮鏡的診断基準

1. 内膜の肥厚形態

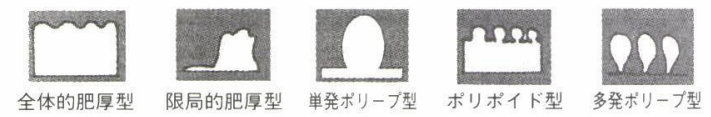

2.血管の不整：表在性の不規則な走行と拡張。比較的平滑な表面 に血管徍の部分的狭寉・蛇行・怒張を認めるもの

3. 腺口の不均一: 比較的平滑な表面に大小不同の腺口とばらつき のある分布を認めるもの。

4. 色調の変化：比較的平滑な表面で黄白色〜灰白色を呈し不透明 なもの。

写真 1 肥厚した内膜に表在性に走行する、枝分かれした血管 の拡張・蛇行・途絶を血管の不整とした。

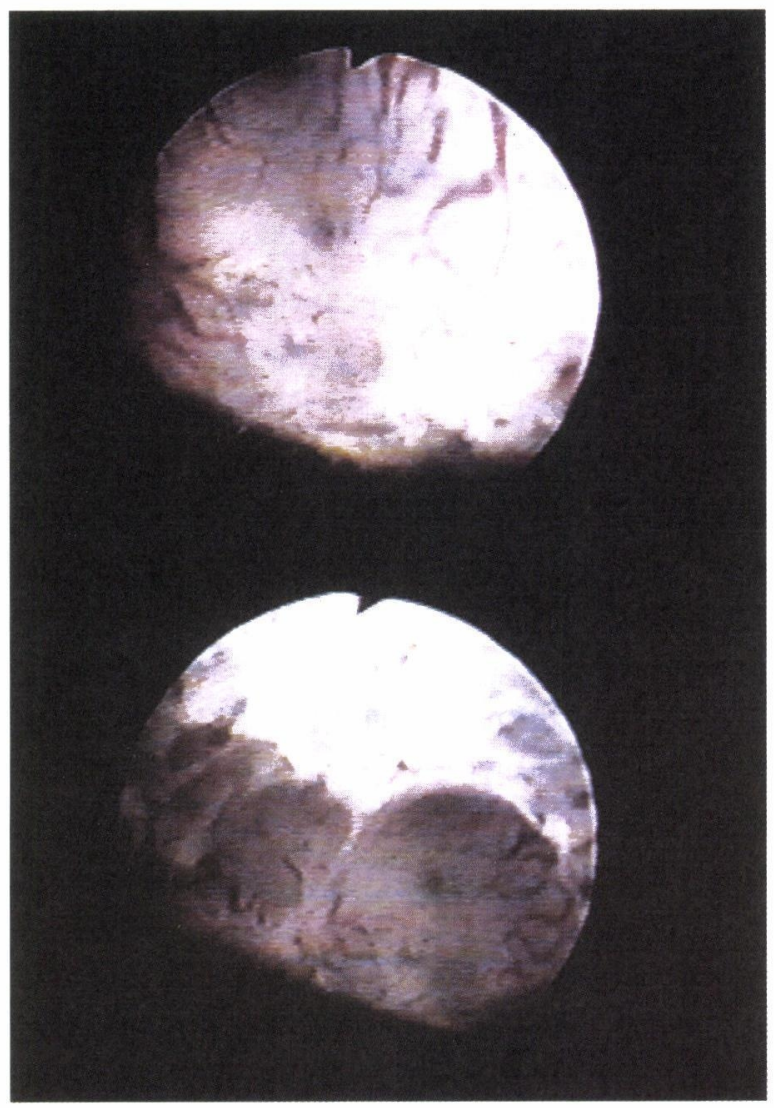

写真 2 大小不同の腺開口が密に・疎に・認められない部分が 混在しているものを腺開口の不均一とした。

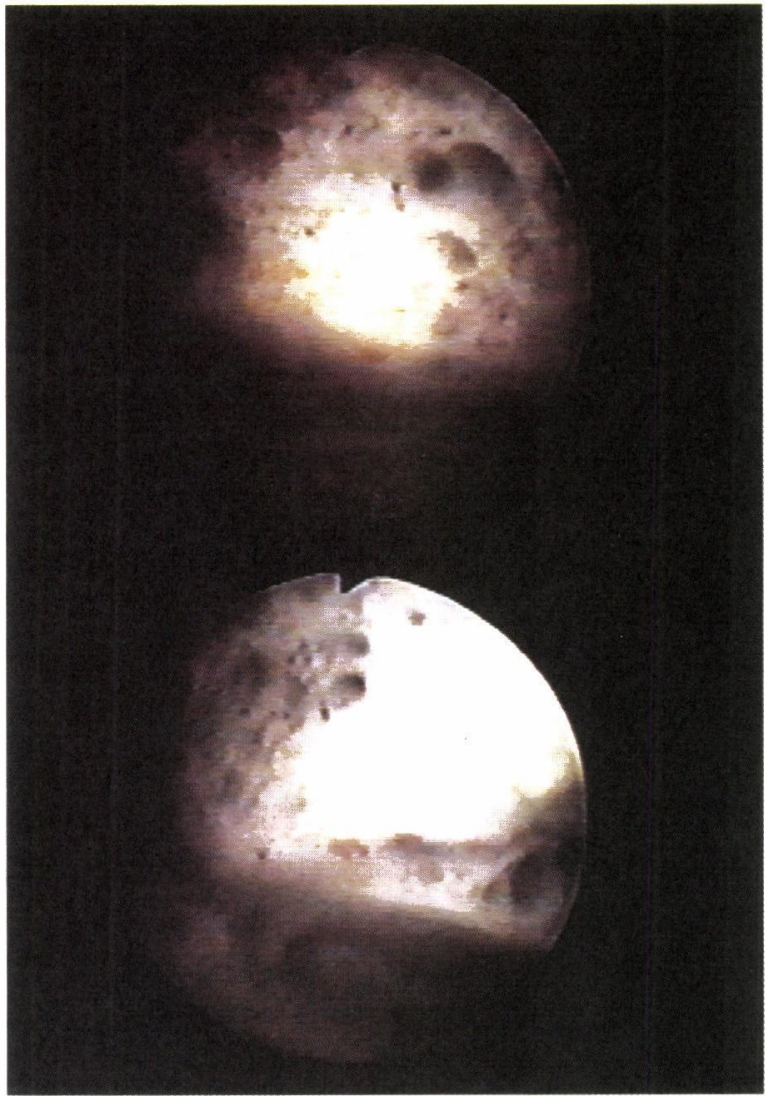

写真 3 不透明な内膜の肥厚を色調の変化としたが、子宮内膜 癌の壊死化した部分とは異なり、一部透明な場合や灰白色を呈 するものもあった。

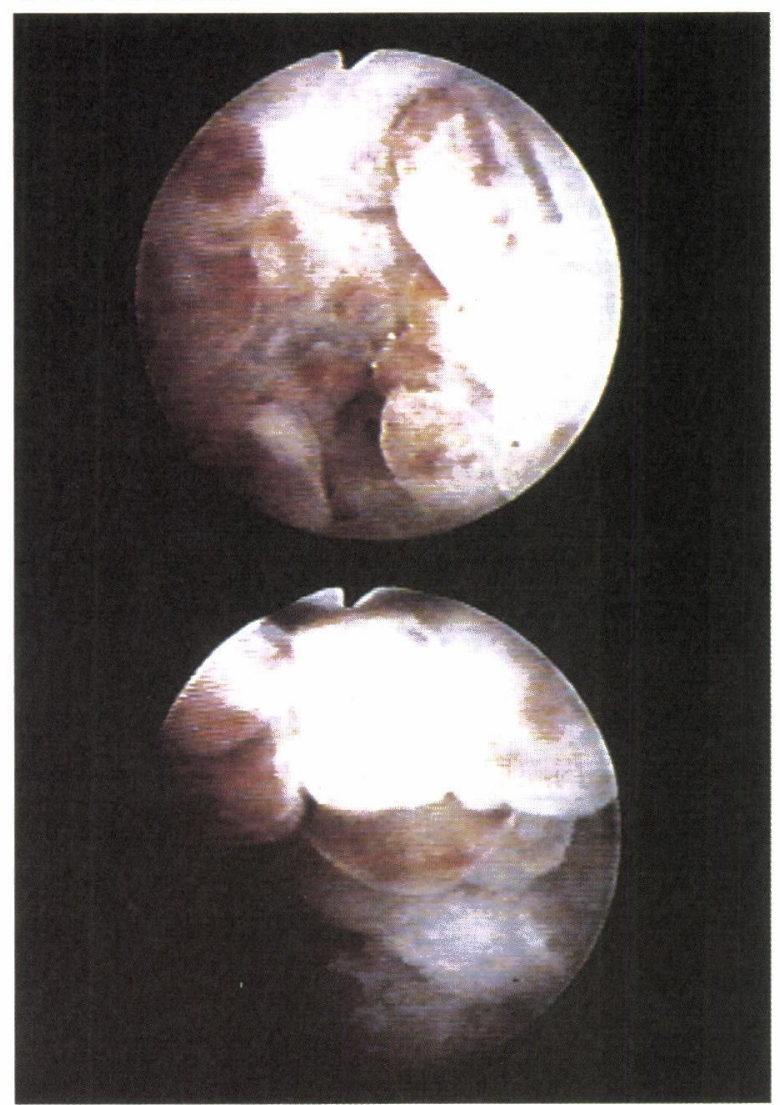




\section{結 果}

子宮鏡検査にて内膜肥厚があり子宮内膜増殖症 を疑った242例中 21 例が、病理組織学的に子宮内 膜異型増殖症であった。その 21 例の臨床像は以下 の如くであった。

主訴：不正性器出血17例（81.0\%）・過多月経 4 例 $(19.0 \%)$

年齢：30 66歳

経産回数：未産婦が 11 例（52.6\%）と半分以上を 占めた。

閉経前の症例が15例（71.4\%）を占め、そのうち 7 例（33.1\%）は子宮温存を希望した。

内膜の肥厚形態については、AEHでなかった 221例は全体的肥厚型123例（55.7\%）、限局的肥厚

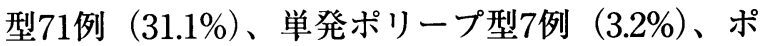
リイド型10例 $(5.0 \%) 、$ 多発ポリープ型10例 (5.0\%) と片寄りがあった。これに対しAEHは全 体的肥厚型 8 例 $(38.1 \%)$ 、限局的肥厚型 2 例 (9.5\%)、単発ポリープ型 4 例 (19.1\%)、ポリポイ ド型 2 例 $(9.5 \%) 、$ 多発ポリープ型 5 例 $(23.8 \%)$ と様々であるが複数混合型はなく、特徵的な所見 はなかった。(図 2)

血管の不整・腺口の不均一・色調の変化に関し ては、腺口の不均一のみ $(\mathrm{V})$ ・色調の変化のみ (C) では一例もなかったのに対して、血管の不 整のみ（V）で 5 例 (23.8\%)、血管の不整+腺 口の不均一＋色調の変化 $(\mathrm{V}+\mathrm{G}+\mathrm{C})$ で 5 例 $(23.8 \%)$ 、血管の不整＋腺口の不均一 $(\mathrm{V}+\mathrm{G})$ で 8例 $(31.8 \%)$ 、血管の不整 +色調の変化 $(\mathrm{V}+\mathrm{C})$ で 3 例（14.3\%）であった。(図 3 )

子宮鏡所見の 4 項目と病理診断結果の関係をま とめると、内膜の肥厚形態 5 亜型のうちいずれか ひとつでも認められた症例は 242 例であり、その うち病理組織学的に $\mathrm{AEH}$ と診断された 21 例 （100\%）すべてに血管の不整（V）を認めた。こ れに対して、腺口の不均一 (G) は13例（61.9\%）、 色調の変化（C）は 8 例（42.1\%）であった。（図 4)

また、病理学的子宮内膜異型増殖症に対する血 管の不整と内膜肥厚を比較した結果 、 positive predictive value（PPV）は血管の不整 $20.8 \%$ 、 内膜肥厚 $6.3 \%$ \%゙った。 negative predictive value（NPV）は、不整血管・内膜肥厚共に $100 \%$ であった。
図 2 内膜の肥厚形態の比率

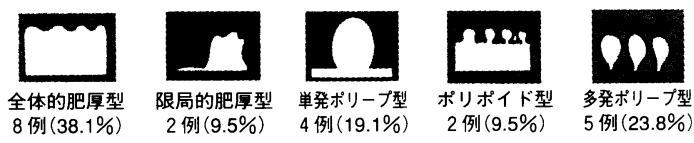

*内膜の肥厚形態においては、AEHに特徵的な所見はない。

図 $3 \mathrm{~V} \cdot \mathrm{G} \cdot \mathrm{C}$ の関係

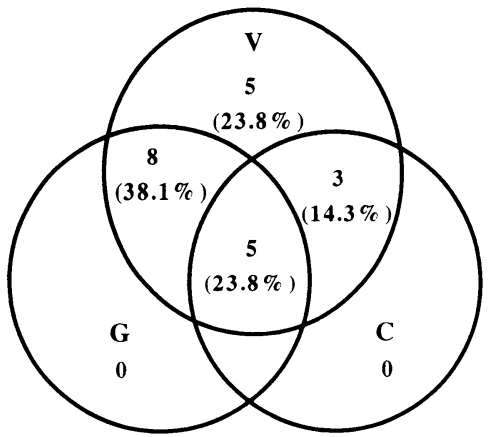

図 4 子宮鏡所見と病理診断結果の関係

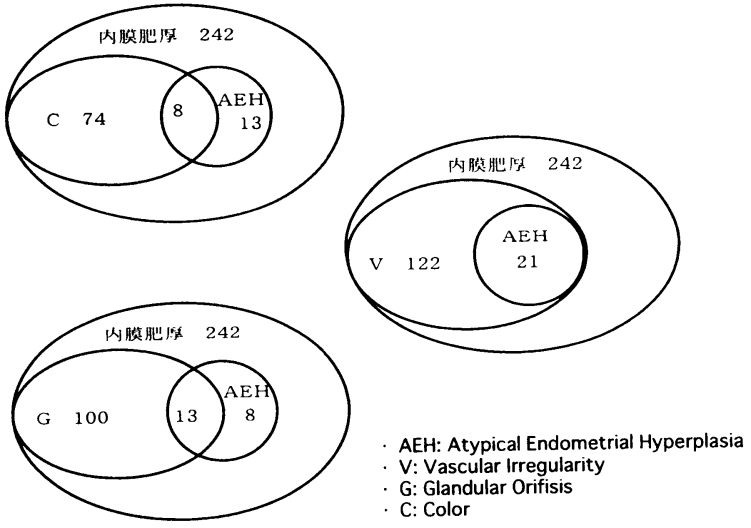

考 察

子宮内膜は月経周期によって肥厚の程度や腺口 の状態、色調などが変化する。その程度には個人 差があり、さらに同一症例でも内分泌動態によっ て月経周期毎に変化する可能性がある。さらには 機械的刺激・炎症・薬物投与などによっても変化 をきたす。このように多彩な変化をきたす子宮内 膜の異常を評価する時、内膜を直視できる子宮鏡 検査は、肥厚の程度や表面の形状だけではなく、 より詳細な性状の観察を可能にする。しかし簡便 性や侵襲性、客観性などを考慮する時、超音波断 層法では得られない子宮鏡ならではの重要所見が 存在するのか、といった点に我々は関心をもった。

子宮内膜増殖症では内膜の肥厚・腺口の不均 一・色調の変化を認めるとする報告が数多くみら れる ${ }^{10,11,12)}$ 。高島は子宮内膜増殖症を形態分類と してポリープ状および肥厚の 2 型に大別して、さ 
らに色調・透明度・異型血管などの有無から他疾 患との鑑別を行い ${ }^{13)}$ 、稲福らは内膜の腺開口に注 目し、その数・分布・大小不同にて腺腫性増殖症 を判別している ${ }^{14)}$ と報告している。しかし、 我々の知るかぎり、肥厚形態の分類は明確にされ ておらず、さらに腺口や色調、血管異常などの各 所見の陽性率は明らかにされていない。そこで今 回我々は、簡便かつ客観性を持った診断基準を作 成するため、既知の報告に基づいて 4 項目の診断 基準を考案し、各々の出現頻度や特異性を検討し た。まず術者の主観による差異を最小化するため、 肥厚形態を 5 亜型に細分類して図式化した。子宮 の内腔に複数の所見が混在する場合には、その部 位と性状をすべて記録した。その結果、内膜の肥 厚形態については、A E H 以外の内膜増殖症の過 半数 $(55.7 \%)$ が全体的肥厚型を呈したのに対し て、A E Hでは部分的肥厚型（限局的、単発ポリ ープ型、ポリポイド型、多発ポリープ型）が多い (61.9\%) 傾向がみられたものの、A E H に特徵 的な所見はなく、いずれの肥厚形態を取り得るこ とが明らかになった。腺口の不均一のみ・色調の 変化のみを呈する A E Hが一例もなかったことか ら、腺口の状態や色調に変化を認めないからとい ってA E Hを否定するものではないことが明らか になった。

またMencagliaらは、子宮内膜癌とその前駆病 変の発見に、子宮鏡検査と内膜組織診の併用が有 用であると述べており、low-risk子宮内膜増殖症 は厚みのある正常子宮内膜に類似し、腺口と囊胞 が認められ、high-risk子宮内膜増殖症は内膜がし ばしば異常に増殖し、ポリポイド状を呈し明らか な血管異型 (corkscrew型)を認めるとしている ${ }^{15.16) 。}$ 今回我々が観察した怒張し蛇行する不整血管は、 Mencagliaらが報告しているcorkscrew型の異型 血管に相当するものと考える。彼らの論文では血 管異型の陽性率は記されていないが、我々の検討 では病理組織学的にAEH と診断された 21 例のう ち腺口の不均一13例 $(61.9 \%)$ ·色調の変化 8 例 （42.1\%）であったのに対し、血管の不整は21例全 例に認めたことから、不整血管の存在がA E Hの 診断に最も重要であることが明らかになった。

ではなぜ不整血管に着目することでpositive predictive value (PPV) が上昇するのであろう か。その理由として我々は、子宮体癌検診におけ る子宮内膜細胞診に関する論議に注目している。

子宮内膜細胞診で増殖症の悪性度を判別する場 合、少なくとも細胞異型と構造異型の 2 点が考慮
される。細胞異型を重視した報告として、 Kurmanらは子宮内膜増殖症には肉眼的にはきわ だった特徵はないとし、細胞異型の有無によって $1 \sim 26$ 年の観察期間中に癌へ進展した頻度を比較 している。その結果、細胞異型のない子宮内膜増 殖症の 122 人中 2 人 $(2 \%)$ に対し、細胞異型の ある子宮内膜異型增殖症の 48 人中 11 人 $(23 \%)$ が 癌に進行しており、両群間に有意差が認められた ことから、細胞異型の鑑別が重要であることを強 調している ${ }^{17)}$ 。

これに対して、近年、細胞異型の弱い高分化型 腺癌の報告などから、子宮内膜増殖症の判定基準 として構造異型を重視する報告がみられる。稲村 らは、吸引法で検体を採取し、圧挫法で標本を作 成することで、構造異型から子宮内膜増殖症以上

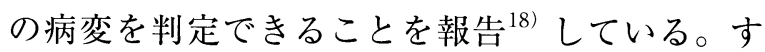
なわち、乳頭状集魂（細胞集魂の辺縁に間質細胞 が直接付着しない多層化上皮細胞集魂）や樹枝状 集魂（長楕円形の核を持つ紡鍾形細胞の束、すな わち Stromal Aを中心に有し、それに直角に上皮 細胞が配列して認められる多層化上皮細胞集魂) の出現頻度や、主に血管と考えられる Stromal A の出現、そしてその束の層数㧍よび分岐の状態を 観察することで悪性度を判別できるとしている。 さらに彼らは、腫瘍細胞が血管の増生を伴って発 育するため、悪性化するにつれて血管の走行も不 整になる、とも述べている ${ }^{19)}$ 。我々が今回観察し た不整血管が、彼らが内膜細胞診で観察している 構造異型、特にStromal A と同一のものであるか、 今後さらに症例を集積して検討したい。

また近年子宮内膜癌は一般的に、高分化型で緩 徐に発育し子宮内膜増殖症を背景に発生する若年 層や閉経前の女性に好発するものと、子宮内膜増 殖症を経ずに萎縮内膜から直接発育する分化度が 低く悪性度が高いとされる閉経後の女性に好発す るものに分けられる、との報告 ${ }^{20.21 .22,23)}$ がある。 特に前者で子宮温存を希望するような症例の場 合、病状の進行を的確に判断し、過不足なく管理 することの重要性が指摘されている ${ }^{24)}$ 。そのため 二次スクリーニング検査には、内膜肥厚の程度と いった量的評価に加え、内膜がどのような状態に あるかという質的評価も求められるのではないだ ろうか。今回の結果でも、病理組織学的に子宮内 膜異型増殖症であった21例のうち、閉経前の症例 が15例 (71.4\%) を占め、そのうち7例 ${ }^{\prime}(33.1 \%)$ が子宮温存を希望した。これらの症例に対して 我々は、MPA (medroxyprogesterone acetate) 
などを用いた保存的治療を行っている。子宮内膜 癌の発生を除外するため、経過観察中は定期的に 経脆超音波検査、子宮鏡検査、内膜細胞診、全面 掻爬による病理検査を行っているが、子宮鏡検査 所見が最も病理診断と一致している。すなわち、 乳頭状突起の中心に怒張・拡張した血管を内膜癌 に特徴的な異型血管とした場合、これらの血管の 出現と組織診上の高分化型腺癌の結果が一致する ことを経験している。尚これらの症例は、子宮鏡 検查自体はすべて無麻酔で施行されており、2 次 スクリーニング検査として侵襲性の点からも問題 がないものと考える。

本研究は、子宮鏡検査で表在性の不整血管を見 落とさなければ、少なくとも under diagnosisを 避けることが可能であることを初めて明らかにし た。子宮鏡所見で異常な内膜肥厚と血管の不整が あった場合には、直ちに子宮内膜掻爬術や狙い組 織生検を行うことが必須であるが、子宮鏡検査は 子宮内膜癌の早期発見のための二次スクリーニン グ検査として有用であると考えられた。

\section{結 論}

不整血管を観察することで、2次スクリーニン グ検査としての子宮鏡検査の正診率が改善される ことが明らかになった。子宮内膜癌の早期発見に 重要とされる病理学的構造異型を簡便にスクリー ニングする補助診断法として、子宮鏡検査で不整 血管を観察することの重要性が確認された。

\section{参考文献}

1) Tirso P-M.et al. : Atypical Endometrial Hyperplasia Treatment with Progestogens and Gonadotropin-Releasing Hormone Analogues:Long-TermFollow-up. Gynecologic Oncology, 73:299, 1999.

2 ) M.M. Tahir.et al. : A randomised controlled trial comparing transvaginal ultrasound, outpatienthysteroscopy and endometrial biopsy with inpatient hysteroscopy and curettage. British Journal of Obstetrics \& Gynecology, 106 : 1259, 1999.

3 ) Loverro G.et al. : Diagnosis of endometrial hyperplasia in women with abnormaluterine bleeding. Acta. Eur, Fertil., 25(1) : 23, 1994.

4 ) L.H. Uno.et al. : Morphologic hysteroscopic criteria suggestive of endometrial hyperplasia. International Journal ofGynecology \& Obstetrics $49: 35,1995$.

5 ) L. Pal..et al. : Comparison of Office Hysteroscopy,
Transvaginal Ultrasonography and Endometrial Biopsy in Evaluation of Abnormal Uterine Bleeding. J Soc Laparoendosc Surg, 1 : 125, 1997.

6 ) Schwarzler P.et al. : An evaluation of sonohysterography and diagnostic hysteroscopy for the assessment of intrauterine pathology. Ultrasound Obstet Gynecol, 11: 337, 1998.

7 ) Widrich T.et al. : Comparison of saline infusion sonography with office hysteroscopy for the evaluation of the endometrium. Am. J. Obstet. Gynecol., 174(4) : 1327, 1996.

8 ) Rafael F.et al. : HYSTEROSCOPIC EVALUATION OF PATIENTS WITH ABNORMAL UTERINE BLEEDING. Surg Genecol Obstet 153 : 521, 1981.

9 ) Iossa A.et al. : Hysteroscopy and endometrial cancer diagnosis: a review of 2007 consecutive examination in self-referred patients. Tumori 77 : $479,1991$.

10) Ohad M.et al. : Dose Hysteroscopy Improve upon the Sensitivity of Dilatation and Curettage in the Diagnosis of Endometrial Hyperplasia or Carcinoma? Gynecologic Oncology 68: 4, 1998.

11) Valli E.et al. : Histological collection in 48 cases of hysteroscopic findings of increased endometrial thickness. Proceedings of the "Biennal Meeting of the International Society for Gynecologic Endoscopy” : October 3, 1991.

12) Loffer F.D. : Hysteroscopy with selective endometrial sampling compared with $\mathrm{D} \& \mathrm{C}$ for abnormal uterine bleeding:the value of a negative hysteroscopic view. Obstet. Gynecol. 73: 16, 1989.

13）高島英世：子宮内膜増殖症および初期内膜癌の子 宮鏡的・組織学的検索、日本婦人科病理・コルポ スコピー学会雑誌、10：116、

14）稲福 薰、中山道男: Adenomatous hyperplasia の子宮鏡による診断一内膜腺口に注目して一、日 本産科婦人科学会雑誌、39:2069、1987.

15) Mencaglia L.et al. : Hysteroscopy and microcolpohysteroscopy in gynecologiconcology, In : Baggish M.S, Barbon J, Valle R.F, editors. Diagnostic and operative hysteroscopy. A text and atras. Philadelphia,PA : Saunders, $1988: 144$.

16) Mencaglia L.et al. : Endometrial carcinoma and its precursors. Int. J. Gynecol. Obstet $31: 107$, 1990.

17) Kurman R.J.et al. : The behavior of endometrial hyperplasia in 170 patients Cancer $56: 403,1985$.

18）稲村千佳子ら：子宮内膜細胞診における高分化型 腺癌と複雑型異型増殖症との比較一Stromal A に 関する検討一、日本臨床細胞学会雑誌、 $37: 567$ 、 1997.

19）小田瑞恵、佐々木寛、藤井雅彦：子宮内膜細胞診 疑陽性についての再検討、日本臨床細胞学会雑誌、 
$33: 1068,1994$.

20) Bokhman, J.V. : Tow pathogenetic types of endometrial carcinoma. Gynecol Oncol $15: 10$, 1983.

21）小畑孝四郎ら：子宮内膜増殖症の組織像、日本臨 床細胞学会雑誌、30：457、1991.

22）森一郎：子宮内膜の細胞学的診断に関する研究 一特に組織構築を中心に一、日本臨床細胞学会雑 誌、32：937、1993.

23）則松良明ら：子宮内膜細胞診における正常内膜、 腺腫性増殖症、高分化型腺癌の組織学的検討一細 胞集塊の比較を中心に一日本臨床細胞学会雑誌、 34:439、1995.

24) Randall T.C.et al. : Progestin treatment of atypical hyperplasia and well- differentiated carcinoma of the endometrium in women under age 40. Obstet. \& Gynec. 90(3) : 434, 1997. 